\title{
HUBUNGAN PEKERJA BASAH DENGAN KEJADIAN DERMATITIS KONTAK AKIBAT KERJAPADA PETUGAS KESEHATAN DI RUMAH SAKIT $X$ TANJUNG, TABALONG, KALIMANTAN SELATAN
}

\author{
WET WORK CORRELATION WITH THE INCIDENCE OF OCCUPATIONAL \\ CONTACT DERMATITIS TO HEALTH CARE IN X HOSPITAL, TANJUNG, \\ TABALONG, KALIMANTAN SELATAN
}

\author{
Rizadin Anshar, Ratih Pramuningtyas, Devi Usdiana \\ Fakultas Kedokteran Universitas Muhammadiyah Surakarta \\ Korespondensi: dr. Ratih Pramuningtyas, SpKK. Email: ratih p@ums.ac.id
}

\begin{abstract}
ABSTRAK
Prevalensi dermatitis kontak akibat kerja (DKAK) di dunia terbilang tinggi. Kontak kulit terhadap iritan atau alergen di tempat kerja dapat mengakibatkan terjadinya DKAK.Petugas kesehatan merupakan salah satu profesi yang berisiko terjadinya DKAK. Hasil survei pendahuluan yang dilakukan di RS X, Tanjung, didapatkan 6 orang menderita DKAK dari 20 petugas kesehatan yang diwawancarai. Penelitian ini bertujuan untuk mengetahui hubungan antara pekerjaan basah dengan kejadian DKAK pada petugas kesehatan. Desain penelitian menggunakan metode observasional analitik dengan pendekatan cross sectional. Jumlah responden penelitian sebanyak 80 petugas kesehatan. Teknik pengambilan sampel menggunakan simple random sampling. Data primer dianalisis dengan uji Chi Square menggunakan program SPSS 17. Hasil penelitian menunjukkan bahwa nilai p = $0,001$ ( $p<0,05)$ yang menunjukkan bahwa terdapat hubungan yang bermakna antara pekerjaan basah dengan kejadian DKAK.Terdapat hubungan yang bermakna antara pekerjaan basah dengan kejadian DKAK pada petugas kesehatan di RS X Tanjung, Tabalong, Kalimantan Selatan.
\end{abstract}

Kata Kunci : Pekerja Basah, Petugas Kesehatan, Dermatitis Kontak Akibat Kerja

\begin{abstract}
Occupational contact dermatitis (OCD) prevalence remains high in the world. Skin contact to the irritant or allergen in work place may cause OCD. Health worker is one of profession having high OCD risk. On the preliminary survey in X hospital, Tanjung, it was found that 6 of 20 health workers got OCD. This research aims at knowing the correlation between wet work with incidence of occupational contact dermatitis to health workers. This research employs analytic observational cross sectional approach. The number of respondents were 80 health worker. The samples were chosen by using simple random sampling. Primary data were analyzed by Chi Square test using SPSS 17 program. The result showed that $p=0,001(p<0,05)$ which imples that there is a significant correlation between wet work with OCD incidence. There is a significant correlation between wet work with OCD incidence to health care in X hospital,Tanjung, Tabalong, Kalimantan Selatan.
\end{abstract}

Keyword: Wet Work, Health Care, Occupational Contact Dermatitis

\section{PENDAHULUAN}

Dermatitis Kontak Akibat Kerja (DKAK) adalah kejadian patologis pada kulit non-infeksi yang terjadi karena pekerja mengalami kontak dengan bahan iritan maupun alergen. Penyakit kulit akibat kerja dapat berupa dermatitis dan urtikaria. Dermatitis kontak merupakan 50\% dari semua PAK (Penyakit Akibat Kerja), terbanyak bersifat non-alergi atau iritan. Dikenal dua jenis dermatitis kontak, yaitu Dermatitis Kontak Iritan (DKI) yang merupakan respon non-imunologi dan Dermatitis Kontak Alergik (DKA) yang diakibatkan oleh mekanisme imunologik spesifik. Keduanya dapat bersifat akut maupun kronik (Nugraha, 2008).

Di dunia, prevalensi DKAK sekitar 68,2\% (Bock et al., 2003). Insiden dari penyakit kulit akibat kerja di beberapa negara adalah sama, 
yaitu 50- 70 kasus per 100.000 pekerja pertahun (Fathiya, 2011). Menurut Health and Safety Executive/HSE (2008) di dalam Budiyanto (2010) menyatakan bahwa antara tahun 2001 sampai 2002 terdapat sekitar 39.000 orang di Inggris terkena penyakit kulit yang disebabkan oleh pekerjaan atau sekitar $80 \%$ dari seluruh penyakit akibat kerja. Berdasarkan laporan dari bagian Penyakit Kulit dan Kelamin Fakultas Kedokteran Universitas Sam Ratulangi Manado, dari tahun 1988-1991 insiden dermatitis kontak di Indonesia tercatat sebesar 4,45\% (Sumantri, 2008).

Dermatitis kontak akibat kerja dapat terjadi pada pekerja salon, pekerja bahan logam, pekerja industri makanan, petugas kebersihan, dan petugas kesehatan akibat seringnya terpapar bahan-bahan iritan di tempat kerja (Behroozy, 2014). Petugas kesehatan termasuk berisiko tinggi terjadinya DKAK terutama perawat, akibat sering kontak dengan bahan iritan dan pekerjaan basah. Perawat yang bertugas di ruang bedah dan unit perawatan khusus, angka kejadian DKAK cukup tinggi yaitu $18 \%$ sampai $57 \%$. Dermatitis kontak akibat kerjapada perawat kesehatan karena banyak agent atau bahan iritan di rumah sakit yang menyebabkan dermatitis kontak iritan seperti air, pekerjaan basah, frekuensi mencuci tangan, cairan antiseptik dan sabun, mengeringkan kulit menggunakan handuk kertas, menggunakan sarung tangan oklusif untuk waktu yang lama dan bubuk sarung tangan (Ngajilo, 2014).

Faktor-faktor risiko DKAK secara garis besar terdiri atas dua macam, yaitu faktor eksogen dan faktor endogen. Faktor eksogen tersebut teridiri atas jenis iritan, penetrasi iritan, suhu tubuh, faktor mekanik, lingkungan, dan faktor lain. Sedangkan faktor endogennya yaitu, dermatitis atopik, permeabilitas kulit, ras, umur, hipersensitivitas kulit (Honari, 2012).

Pekerjaan basah dapat didefinisikan sebagai kegiatan di mana para pekerja harus membenamkan tangan mereka dalam cairan selama $>2$ jam per hari, atau memakai sarung tangan untuk jumlah yang sesuai waktu, atau mencuci tangan mereka> 20 kali per hari (Behroozy, 2014). Penelitian yang dilakukan Nursecha pada tahun 2013, didapatkan dari 55 petugas kesehatan di RS Sukuharjo yang rutin memakai handscoon latex $>4$ perhari, yang mengalami DKAK 28 0rang. Penelitian tentang hubungan pekerja basah terhadap kejadian dermatitis kontak juga sudah diteliti oleh Febrianti dari Fakultas Kedokteran Universitas Sriwijaya, bedanya dengan penelitian saya yaitu pada variabel terikat dimana penelitian Febrianti hanya meneliti kejadian DKI saja tanpa memperhitungkan DKA.

Berdasarkan ulasan diatas, peneliti tertarik untuk melakukan penelitian DKAK, dimana DKAK ini terdiri dari DKI dan DKA terhadap pekerja basah pada petugas di Rumah Sakit yang termasuk kriteria 'pekerja-basah'. Alasan mengapa memilih tempat penelitian di Kalimantan Selatan, kerena rumah sakit tersebut merupakan RS rujukan dari beberapa puskesmas sehingga intensitas cuci tangan dan paparan iritan serta alergen saat bekerja relatif tinggi.

\section{METODE}

Penelitian ini bersifat observasional analitik dengan pendekatan cross sectional. Penelitian dilakukan di Rumah Sakit Umum Daerah H. Badaruddin, Kota Tanjung, Kabupaten Tabalong, Provinsi Kalimantan Selatan pada bulan Desember 2015. Populasi target pada penelitian ini adalah petugas kesehatan di rumah sakit yang termasuk dalam golongan pekerja basah dan bukan pekerja basah. Populasi aktual penelitian ini adalah petugas kesehatan di Rumah Sakit Umum Daerah H. Badaruddin, Kota Tanjung, Kabupaten Tabalong, Provinsi Kalimantan Selatan.Sampel pada penelitian ini adalah petugas kesehatan di Rumah Sakit Umum Daerah H. Badaruddin, Kota Tanjung Kabupaten Tabalong, Provinsi Kalimantan Selatan yang memenuhi kriteria restriksi.Teknik Sampling dilakukan dengan simple random sampling.

Analisa data yang digunakan dalam penelitian ini adalah analisa data dengan program SPSS 17 for windows seven. Untuk menghitung uji statistik digunakan uji Chi Square, dinyatakan bermakna jika nilai $\mathrm{p}<0,05$ dan dinyatakan tidak bermakna jika nilai $\mathrm{p}>0,05$.

\section{HASIL DAN PEMBAHASAN}

\section{Karakteristik Tempat Penelitian}

RS X , Tanjung merupakan satu diantara dua Rumah Sakit yang terdapat di Kabupaten Tabalong, dengan status Rumah Sakit milik pemerintah menjadikan Rumah Sakit ini rujukan dari puskesmaspuskesmas yang ada di wilayah Tabalong. 
RS ini memiliki jumlah pasien dan karyawan lebih banyak dibanding Rumah Sakit lainnya di kabupaten ini, Jumlah pasien perhari sebanyak 90 orang, dan jumlah ruang inap sebanyak 91 ruangan.

2. Karakteristik Responden

a. Usia

Tabel 1. Karakteristik Usia Responden

\begin{tabular}{cccccccc}
\hline $\mathbf{2 1 - 3 0}$ & & $\mathbf{3 1 - 4 0}$ & & $\mathbf{4 1 - 5 0}$ & \multicolumn{3}{c}{$\mathbf{5 1 - 6 0}$} \\
\hline $\mathbf{N}$ & $\mathbf{\%}$ & $\mathbf{N}$ & $\mathbf{\%}$ & $\mathbf{N}$ & $\mathbf{\%}$ & $\mathbf{N}$ & $\mathbf{\%}$ \\
\hline 24 & 30 & 38 & 47,5 & 15 & 18,8 & 3 & 3,8 \\
\hline
\end{tabular}

(Sumber: Data Primer, Desember 2015)

Hasil analisis distribusi usia responden menunjukkan kelompok usia 21-30 dan 3140 merupakan kelompok usia terbanyak, yaitu kelompok usia 21-30 sebanyak 24 orang dan kelompok usia 31-40 sebanyak 38 orang.

b. Jenis Kelamin

Tabel 2. Karakteristik Jenis Kelamin

\begin{tabular}{lll}
\hline \multicolumn{1}{c}{$\mathbf{N}$} & $\mathbf{\%}$ & \\
\hline Laki-Laki & 12 & 15 \\
\hline Perempuan & 68 & 85 \\
\hline
\end{tabular}

(Sumber: Data Primer, Desember 2015)

Hasil analisis distribusi jenis kelamin responden menunjukkan jenis kelamin perempuan lebih banyak dibanding laki-laki.

c. Profesi

Tabel 3. Karakteristik Profesi Responden

\begin{tabular}{lll}
\hline \multicolumn{1}{c}{$\mathbf{N}$} & \multicolumn{1}{l}{$\%$} \\
\hline Perawat & 41 & 51,3 \\
\hline Bidan & 16 & 20 \\
\hline Analis Kesehatan & 7 & 8,8 \\
\hline Ahli Gizi & 5 & 6,3 \\
\hline Radiografer & 5 & 6,3 \\
\hline Petugas laundry & 3 & 3,8 \\
\hline Juru Masak & 3 & 3,8 \\
\hline
\end{tabular}

(Sumber: Data Primer, Desember 2015)

Hasil analisis distribusi jenis-jenis profesi responden menunjukkan profesi Perawat, Bidan, merupakan paling banyak. Terdapat 41 orang Perawat (51,3\%) dan 16 orang Bidan $(20 \%)$.

d. Hubungan Pekerjaan Basah dengan Kejadian DKAK

Tabel 4 Distribusi Pekerjaan Basah terhadap Kejadian DKAK

\begin{tabular}{|l|c|c|c|c|}
\hline \multirow{2}{*}{} & \multicolumn{2}{|c|}{ DKAK (+) } & \multicolumn{2}{c|}{ DKAK (-) } \\
\cline { 2 - 5 } & $\mathbf{N}$ & $\mathbf{\%}$ & $\mathbf{N}$ & $\mathbf{\%}$ \\
\hline Pekerja Basah & 16 & 30,2 & 37 & 69,8 \\
\hline Bukan Pekerja Basah & 0 & 0 & 27 & 100 \\
\hline
\end{tabular}

(Sumber: Data Primer, Desember 2015) 
Tabel di atas menunjukkan bahwa Petugas Kesehatan yang termasuk pekerja basah dan terdiagnosa DKAK sebanyak 16 orang atau $(30,2 \%$,), sedangkan Petugas Kesehatan yang tidak termasuk pekerja basah tidak ada yang mengalami DKAK.

Mayoritas usia responden adalah kelompok usia 21-30 dan 31-40 dengan jumlah 62 orang, terdapat 13 orang $(21 \%)$ yang positif menderita DKAK, sedangkan kelompok usia 41-50 dan 5160 dengan jumlah 18 orang, terdapat 3 orang $(16,7$ $\%)$ positif menderita DKAK. Penelitian ini tidak menganalisa usia terhadap kejadian DKAK, karena mayoritas proporsi tiap-tiap kelompok usia tidak sama. Menurut penelitian yang dilakukan Utami (2014), tidak ada hubungan antara usia dengan kejadian DKAK dengan $p$ value $=0,220$, namun usia dapat menjadi faktor protektif kulit, menurut Cohen (2008) usia muda dapat memberikan perlindungan yang lebih baik terhadap kulit karena lapisan lemak kulit yang bagus sehingga agen infeksi lebih sulit untuk menembusnya.

Hasil penelitian terhadap jenis kelamin menunjukkan bahwa perempuan lebih banyak menderita DKAK dibanding laki-laki, yaitu dari 12 orang laki-laki, terdapat 1 orang yang menderita DKAK, sedangkan perempuan yaitu dari 68 orang terdapat 15 orang menderita DKAK. Sebagian besar Perawat dan Bidan adalah perempuan. Besdasarkan Aesthetic Surgery Journal, perempuan memiliki jumlah folikel rambut lebih sedikit, kelenjar keringat dan hormon serta kulit lebih tipis daripada kulit laki-laki, sehingga perempuan mudah terkena DKAK.

Hasil penelitian terhadap profesi menunjukkan, dari 41 orang Perawat terdapat 7 orang yang menderita DKAK, dari 16 orang Bidan terdapat 5 orang yang menderita DKAK, dari 7 orang Analis Kesehatan terdapat 1 orang yang menderita DKAK, dari 5 orang Ahli Gizi terdapat 1 orang yang menderita DKAK, dari 3 orang Petugas Laundry terdapat 2 orang yang menderita DKAK, dari 5 orang Radiografer tidak ada yang menderita DKAK, dan dari 3 orang juru masak tidak ada yang menderita DKAK (Lampiran 3). Perawat, Bidan, dan Petugas Laundry merupakan 3 profesi yang paling banyak menderita DKAK, hal ini karena pekerjaan mereka yang sering terpapar air dan handscoon latex. Air dan handscoon latex merupakan bahan iritan yang berpotensi mengakibatkan dermatitis pada tangan (Perry, 2009).

DKAK terdiri atas dua bentuk, DKAK akibat bahan iritan dan DKAK akibat alergen, yang paling sering yaitu DKAK akibat bahan iritan (Djuanda, 2007), hal ini sesuai dengan hasil penelitian ini yang menunjukkan Petugas Kesehatan yang sering terpapar bahan iritan berupa air terdapat 9 orang yang menderita DKAK, sedangkan pemakaian handscoon ada 3 orang yang menderita DKAK, dan yang terpapar air dan menggunakan handscoon terdapat 4 orang yang menderita DKAK. Untuk menentukan DKAK yang disebabkan oleh DKI atau DKA perlu dilakukan patch test atau test tempel.

DKI terjadi akibat adanya iritasi (baik kimia dan fisik), menyebabkan kerusakan sel jika dibiarkan untuk waktu yang cukup dan dalam konsentrasi yang memadai.Dermatitis kontak iritan terjadi ketika kapasitas pertahanan atau perbaikan kulit tidak dapat mempertahankan integritas kulit normal dan fungsi atau ketika penetrasi kimia menginduksi respon inflamasi. Sedikit dari iritan yang dapat menyebabkan reaksi setelah kontak. Reaksi awal biasanya terbatas pada tempat kontak dengan iritan tersebut, konsentrasi iritan menyebarkan luar daerah kontak hampir selalu turun di bawah ambang batas kritis yang diperlukan untuk memprovokasi reaksi.Mekanisme yang terlibat dalam fase akut dan kronis dari DKI pada dasarnya berbeda. Reaksi akut melibatkan kerusakan sitotoksik langsung ke keratinosit. Hasil DKI kronis dari eksposur berulang yang menyebabkan kerusakan lambat untuk membran sel, mengganggu jaringan pelindung kulit dan menyebabkan denaturasi protein dan toksisitas seluler (Tardan, 2012). Pada penelitian ini bahan yang mungkin menyebabkan terjadinya DKI adalah air, karena air merupakan iritan ringan yang bisa mengiritasi kulit jika terpapar terlalu lama (Djuanda, 2013).

DKA merupakan reaksi imun tipe lambat, proses ini terdiri atas dua fase, yaitu fase sensitasi dan fase elikasi atau elisitasi. Fase sensitasi adalah pengenalan alergenyanglipofilikdan kecil (< 1000D) molekul mampu menembus stratum korneumd an mencapai sel-sel antigenpresentingcell(APC) di epidermis(sel Langerhans) 
atau dermis(sel dendritik dermal). Zat kimia ini merupakan antigen lengkap, atau haptens, yang harus ditangkap oleh APC, diinternalisasi, terikat dengan protein kompleks histokompatibilitas utama, dan muncul kembali pada permukaan sel untuk menjadi antigen lengkap. Antigen Presenting Cell (APC) bermigrasi kekelenjar getah bening lokal,dimana mereka menyajikan alergen yang baru untuk mempresentasikan pada selTnaif. Limfosit ini kemudian mengalami proliferasi klonal dan diferensiasi menjadi CD4 dan CD8 sel efektor, penekan, dan memori yang dibebaskan dalam aliran darah. Proses ini berlangsung selama10 sampai 15 hari dan jarang menimbulkan lesi kulityang terlihat. Fase elikasi atau elisitasi murupakan paparan ulang alergen yang mengakibatkan selT menghasilkan IL-1, IL-2, dan interferon-c. Limfokin ini menginduksi proliferasi sel T sitotoksik dan rekrutmen terhadap makrofag,dalam waktu 8 sampai 48 jam, selselefektor ini dan sitokin proinflamasi mereka akan menyerang epidermis dan menghasilkan gambaran klinis dari dermatitis, tanpa pengobatan biasanya proses ini mungkin berlangsung selama beberapa hari atau minggu, sampai sel-sel yang berfungsi sebagai penekan atau supresor mengeluarkan interleukin, terutamaIL-4 danIL-10 mengambil alih dan menghambat reaksi. Walaupu ntanda-tanda klinis dari DKI dan DKA sering tumpang tindih dan tidak selalu dapat dibedakan, DKA cenderung bermanifestasi sebagai akut hingga subakut, dengan pruritus sebagai tanda kardinalnya. Pada individu peka, konsentrasi alergen yang dibutuhkanuntuk menginduksi lesi mungkin sangat rendah(Sasseville, 2008). Pada penelitian ini bahan yang mungkin mengakibatkan DKA adalah handscoon latex, karena handscoon dari bahan latex adalah alergen yang potensial mengakibatkan DKA pada petugas kesehatan (Buss, 2007).Paparan antigen lateks terjadi melalui kontak langsung dengan membran mukosa kulit yang dibawa oleh partikel protein serbuk sarung tangan lateks.Penyerapan protein lateks melalui kulit merupakan jalur utama sensitisasi, dan bertanggungjawab atas munculnya manifestasi lokal urtikaria yang akhirnya dapat menjadi sistemik. Peristiwa ini terkait dengan pemakaian sarung tangan lateks jangka panjang (Taylor, 2004).

Pekerjaan basah merupakan faktor risiko utama terjadinya DKAK pada Petugas Kesehatan di Rumah Sakit, karena kontak dengan bahan iritan ataupun alergen di tempat kerja. Selama bekerja, Petugas Kesehatan wajib mencuci tangan dan menggunakan handscoon sebelum tindakan terhadap pasien, sedangkan mencuci tangan dan penggunaan handscoon merupakan faktor yang mengakibatkan terjadinya DKAK, sehingga kejadian DKAK pada Petugas Kesehatan sulit untuk dihindari (Smith, 2005).

DKAK sudah banyak diteliti hubungannya dengan pekerjaan basah, dan hasilnya adalah terdapat hubungan antara kedua variabel. Penelitian yang dilakukan oleh Behroozy (2014) juga menjelaskan hal yang sama bahwa ada hubungan antara pekerjaan basah dengan kejadian DKAK. Sesuai dengan hasil penelitian ini dengan nilai $p$ value $=0,001$.

\section{KESIMPULAN}

Berdasarkan hasil penelitian yang dilakukan, menunjukkan adanya hubungan antara pekerjaan basah dengan kejadian DKAK pada petugas kesehatan di RS X, Tanjung, Tabalong, Kalimantan Selatan.

\section{PERSANTUNAN}

Ucapan terima kasih kepada petugas kesehatan RS $\mathrm{X}$, Tanjung, Tabalong, Kalimantan Selatan yang telah membantu jalannya penelitian ini dan atas kesediaannya untuk menjadi responden dalam penelitian.

\section{DAFTAR PUSTAKA}

Behroozy, A., \& Keegel, T.G. 2014. A Main Risk Factor for Occupational Hand Dermatitis. Elsevier. Vol 5: (175-180)

Bock, M., Schimdt, A., Bruckner, T., \& Diepgen, T.L. 2003. Contact Dermatitis and Allergy, Occupational Skin Disease in The Construction Industry.British Journal of Dermatology. Vol 21: (45-51)

Buss, Z.S., \& Frode, S.S. 2007. Latex Allergen Sensitization and Risk Factor Due To Glove use by Health Care Workers at Public Health Units in Florianopolis Brazil, J Investig Allergol Clin Immunol 2007; Vol. 17(1):27-33 
Djuanda, A., Hamzah, M., \& Aisah, S. 2013. Ilmu Penyakit Kulit dan Kelamin. Jakarta: Universitas Indonesia.

Fathiya, I. 2011. Dermatitis Kontak Iritan dengan Sekunder Infeksi.Diakses pada tanggal 23 Juli 2015.http://www.fkumyecase.net/ wiki/index. php?page $=$ DERMATITIS + KONTAK+ IRITAN+ DENGAN+ SEKUNDER+INFEKSI+EC+SABUN

Health and Safety Executive . 2008. Work Related Contact Dermatitis. Inggris Raya

Honari, G., Taylor, J.S., \& Sood, A. 2012. Occupational Skin Diseases Due To Irritants And Allergens At Glance in: Fitszpatrick's Dermatology in General Medicine, $8^{\text {th }}$ Edition.McGraw-Hill's: 3716-3732

Ngajilo. 2014. Occupational Contact Dermatitis Among Nurses. Diakses pada tanggal 22 Juli 2015.http:www.sabinet.co.za-irritantcontact-dermatitis-and-allergic-contactdermatitis? mobile $=$ no $\% 5$ Fmobile

Nugraha, W. 2008.Faktor-Faktor yang Mempengaruhi Kejadian Dermatitis Kontak pada Karyawan yang Terpajan dengan Bahan Kimia di Perusahaan Industri
Otomotif Kawasan Industri Cibitung Jawa Barat.Thesis

Perry, A.D., \& Trafeli J.P. 2009. Hand Dermatitis: Review of Etiology, Diagnosis, and Treatment. United States Navy, Camp Pendleton Naval Hospital, California. Vol. 22: (325-330)

Sasseville, D. 2008. Occupational Contact Dermatitis.McGill University Health Centre, Montreal, QC. Vol 4: (59-65)

Smith, R.D., Wei, N., Zhao, L., \& Wang, S.R. 2005.Hand Dermatitis Among Nurses In A Newly Developing Region Of Mainland China. International Journal Of Nursing Studies. Vol 42: (13-19).

Sumantri. 2008. Dermatitis Kontak. Jogjakarta : Universitas Gajah Mada.

Tardan, M.P.C., \& Zug, A.K. 2012.Allergic Contact Dermatitis in: Fitszpatrick's Dermatology in General Medicine, $8^{\text {th }}$ Edition. McGrawHill's: 244-260

Taylor, J. S., Erkek, E. 2004. Latex Allergy: Diagnosis and Management. Dermatol Ther:; 17:289-301. 